\title{
Rancang Bangun Alat Pengering Biji Kopi Berbasis Internet Of Things
}

\author{
Asyiva Nurbaeti ${ }^{1}$, Mila Kusumawardani ${ }^{2}$, Hendro Darmono \\ ${ }^{1,3}$ Program Studi Jaringan Telekomunikasi Digital, \\ Jurusan Teknik Elektro, Politeknik Negeri Malang, Indonesia \\ ${ }^{2}$ Program Studi Teknik Telekomunikasi, \\ Jurusan Teknik Elektro, Politeknik Negeri Malang, Indonesia
}

11AsyivaNurbaeti73@gmail.com, ${ }^{2}$ mila.kusumawardani@polinema.ac.id, ${ }^{3}$ hendro.darmono@polinema.ac.id

\begin{abstract}
This research propose to design a coffee bean dryer by utilizing a heater as a heating element to replace sunlight for the drying process of coffee beans. Ultrasonic sensor for detecting coffee beans in the dryer. When the temperature reaches $50^{\circ} \mathrm{C}$, the heater, dimmer and fan will automatically turn off. All data will be processed using NodeMCU which will then be sent to the codular application. By utilizing IoT (Internet Of Things) technology, it is hoped that it can help smallholder coffee farming owners in monitoring and automatic drying of the coffee beans to be dried. From the test results, it can be concluded that the initial weight before curing is $\mathbf{2 5 0}$ grams, while the weight after curing is $\mathbf{2 4 7}$ grams. This is because there is a decrease in the water content in the coffee beans. The DHT22 sensor is able to measure an average temperature of around $49.75^{\circ} \mathrm{C}$ with an average humidity of $51.45 \%$ during the day, while for the night it is able to measure an average temperature of around $49.75^{\circ} \mathrm{C}$ with an average humidity of around $46.8 \%$. The process of sending information from the device to Google Firebase via an internet connection, which takes an average of 0.01 seconds or 10 milliseconds, with this delay is included in the very good category.
\end{abstract}

Keywords-Coffee bean dryer, heating element, DHT22, motor driver L298N, Kodular application.

Abstrak-Penelitian ini bertujuan untuk merancang sebuah alat pengering biji kopi dengan memanfaatkan heater sebagai elemen pemanas pengganti sinar matahari untuk proses mengeringkan biji kopi. Ketika suhu telah mencapai $50^{\circ} \mathrm{C}$ maka heater, dimmer dan kipas akan off secara otomatis. Semua data tersebut akan diproses menggunakan NodeMCU yang kemudian dikirimkan ke aplikasi kodular. Dengan memanfaatkan teknologi IoT (Internet Of Things) diharapkan dapat membantu para pemilik usaha tani kopi rakyat dalam monitoring dan pengeringan otomatis kepada biji kopi yang akan dikeringkan. Dari hasil pengujian dapat disimpulkan bahwa untuk berat awal sebelum pemeraman sebesar 250 gram sedangkan berat setelah pemeraman sebesar 247 gram. Hal ini dikarenakan terjadi penurunan kadar air dalam biji kopi. Sensor DHT22 mampu mengukur suhu rata - rata berkisar $49,75^{\circ} \mathrm{C}$ dengan kelembaban rata - rata berkisar $51,45 \%$ untuk siang hari, sedangkan untuk malam hari mampu mengukur suhu rata - rata berkisar $49,75^{\circ} \mathrm{C}$ dengan kelembaban rata - rata berkisar 46,8\%. Proses pengiriman informasi dari perangkat menuju ke firebase google melalui koneksi internet yakni dibutuhkan waktu rata-rata 0,01 second atau 10 milisecond dengan ini delay termasuk dalam kategori sangat baik.

Kata Kunci-Alat pengering biji kopi, elemen pemanas, DHT22, driver motor L298N, Aplikasi Kodular

\section{PENDAHULUAN}

Kopi merupakan tanaman yang banyak dibudidayakan di negara tropis. Kopi yang populer dibudayakan di Indonesia adalah kopi robusta dan kopi arabika. Kopi juga merupakan jenis minuman yang penting bagi sebagian masyarakat dunia. Bulan panen kopi biasanya antara bulan Mei September dengan puncak panen bulan Juli - Agustus [1]. Kopi diolah dengan beberapa cara pengolahan yaitu pengolahan basah dan pengolahan kering. Pada penelitian ini menggunakan pengolahan basah dengan cara menggunakan air untuk pengupasan maupun pencucian buah kopi. Salah satu tahapan pengolahan basah kopi arabika yang sangat menentukan mutu adalah fermentasi. Fermentasi bertujuan untuk menghilangkan lapisan lendir yang tersisa di permukaan kulit tanduk biji kopi setelah proses pengupasan. Selama proses fermentasi, akan terjadi pemecahan komponen lapisan lendir (protopektin dan gula) dengan dihasilkannya asam-asam dan alkohol [2][3]. Buah kopi yang digunakan pada penelitian ini adalah buah kopi gelondong basah yang buah kopinya hasil panen dari kebun dan kadar airnya masih berkisar antara 60 - 65\% [2].

Pengeringan kopi merupakan salah satu tahapan terpenting dalam pengolahan biji kopi. Di Indonesia pengeringan kopi selama ini dilakukan pada lantai yang luas dengan memanfaatkan sinar matahari. Namun pengeringan ini memiliki kelemahan yaitu cuaca yang sulit diprediksi dan ketika hujan tiba maka dibutuhkan banyak sumber daya manusia untuk mengumpulkan biji kopi yang sedang dijemur. Selain itu apabila memasuki musim hujan proses pengeringan biji kopi membutuhkan waktu 1-2 minggu bahkan lebih, tergantung intensitas hujan pada waktu pengeringan biji kopi [3][4].

Untuk mengatasi masalah tersebut diperlukan sebuah alat pengering biji kopi secara mekanis untuk mengikuti kondisi cuaca. Selain itu kebersihan biji kopi dapat terjamin dan tidak terjadi penyusutan akibat dimakan hewan pemakan biji-bijian [5].

Sensor DHT22 digunakan untuk mengukur suhu dan kelembaban mesin pengering. Dimmer AC digunakan untuk 
mengatur on/off heater. Kipas (fan) digunakan untuk mengatur sirkulasi udara dalam mesin pengering. Driver motor digunakan untuk mengatur on/off kipas (fan). Sensor ultrasonik HCSRF-04 digunakan untuk mendeteksi keberadaan biji kopi di dalam mesin pengering.

Dengan memanfaatkan teknologi IoT (Internet Of Things) diharapkan dapat membantu para pemilik usaha tani kopi rakyat dalam monitoring dan pengeringan otomatis kepada biji kopi yang akan dikeringkan. IoT merupakan segala aktifitas yang dilakukan dengan memanfaatkan internet atau jaringan sebagai media untuk berkomunikasi satu dengan lainnya [4]. Selain itu manfaat dari Internet Of Things ialah dari aplikasi kodular dapat mengambil data berupa suhu, kelembaban, waktu pengeringan dan kondisi biji kopi dari firebase sehingga dapat di monitoring melalui aplikasi kodular.

Hasil pembacaan masing-masing sensor akan diolah oleh NodeMCU ESP8266 sebagai mikrokontroller dan data yang diperoleh dikirimkan ke database melalui jaringan internet[5-7]. Pada sistem ini menggunakan aplikasi kodular untuk menampilkan informasi data dari database berupa suhu, kelembaban relatif udara dalam mesin pengering, waktu pengeringan dan kondisi biji kopi (wet dan dry).

\section{METODE}

Metode penelitian yang dilakukan pada pembuatan jurnal ini adalah melakukan beberapa tahap mulai dari studi literatur, perencanaan hardware, perencanaan software sampai ke proses pembuatan hingga implementasi dari sistem yang telah dibuat.

Pada gambar 1 menjelaskan bahwa perangkat penelitian terdiri dari biji kopi, sensor DHT22, sensor ultrasonik, heater, dimmer AC, driver motor stepper L298N dan kipas.

Sedangkan pada gambar 2 menjelaskan tentang flowchart sistem pengeringan biji kopi. Sebelum melakukan proses pengeringan biji kopi langkah pertama yang harus dilakukan adalah menimbang biji kopi sebanyak $1 / 4 \mathrm{~kg}$. Setelah itu memasukkan biji kopi ke dalam mesin pengering. Kemudian memanfaatkan sensor jarak yang ada pada sensor ultrasonik untuk mendeteksi biji kopi yang telah dimasukkan kedalam box pengeringan, apabila jarak yang terdeteksi oleh sensor ultrasonik kurang dari $10 \mathrm{~cm}$ maka secara otomatis biji kopi terdeteksi oleh sensor ultrasonik dan proses pengeringan dapat dilakukan[8-11]. Ketika suhu $<50{ }^{\circ} \mathrm{C}$ maka dimmer dan fan dalam posisi ON. Ketika suhu mencapai $>==50{ }^{\circ} \mathrm{C}$ maka dimmer dan fan dalam posisi OFF, sehingga proses pengeringan biji kopi selesai dan biji kopi yang telah dikeringkan dapat dikeluarkan dari mesin pengering.
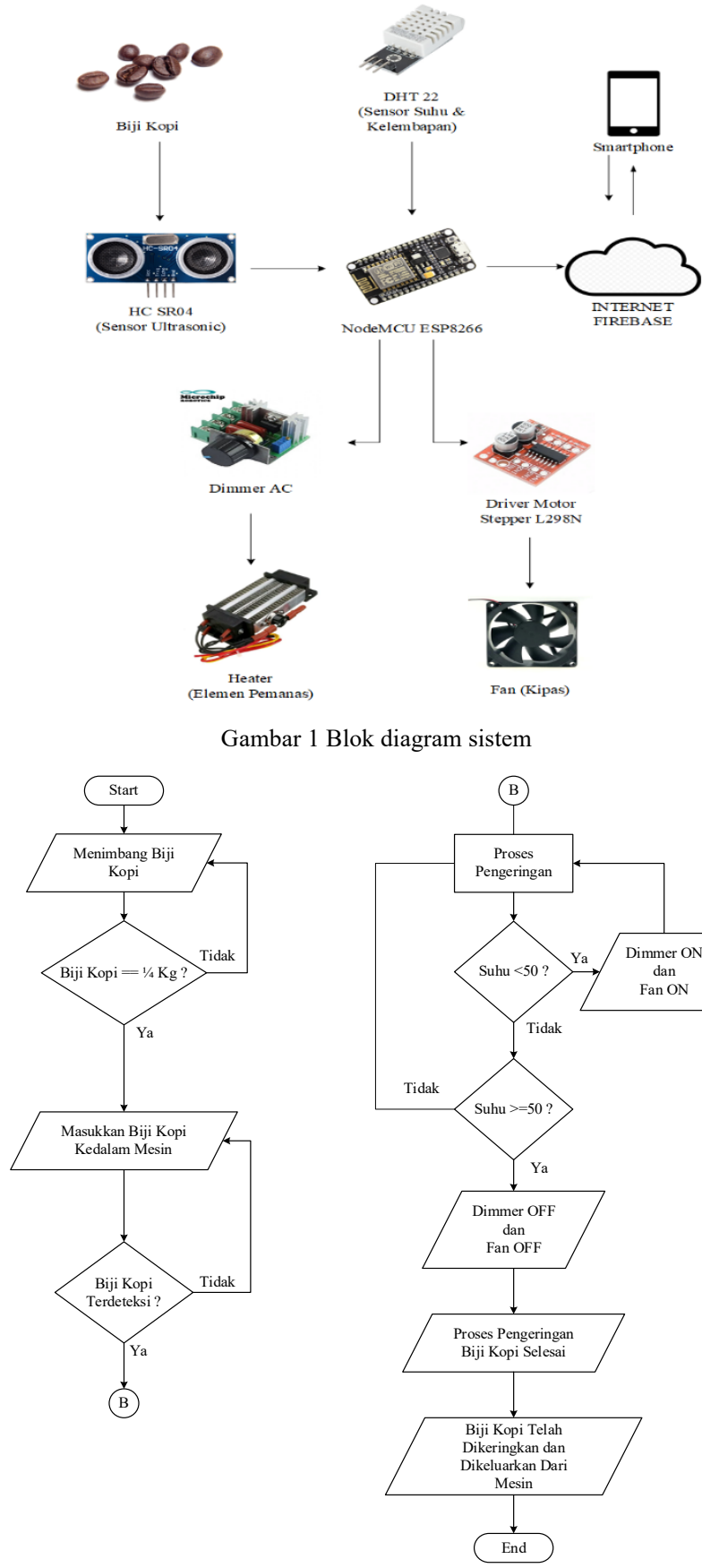

Gambar 2 Flowchart sistem keseluruhan

Desain alat dirancang dengan menggunakan 2 sensor yang terdiri diri sensor ultrasonik HC-SR04 dan sensor DHT22. Kemudian NodeMCU ESP8266, dimmer module AC dan driver motor L298N [12-16].

Desain tampilan software menggunakan aplikasi kodular yang dirancang untuk monitoring pengeringan biji kopi yang terdiri dari suhu, kelembaban, waktu pengeringan dan kondisi biji kopi. 


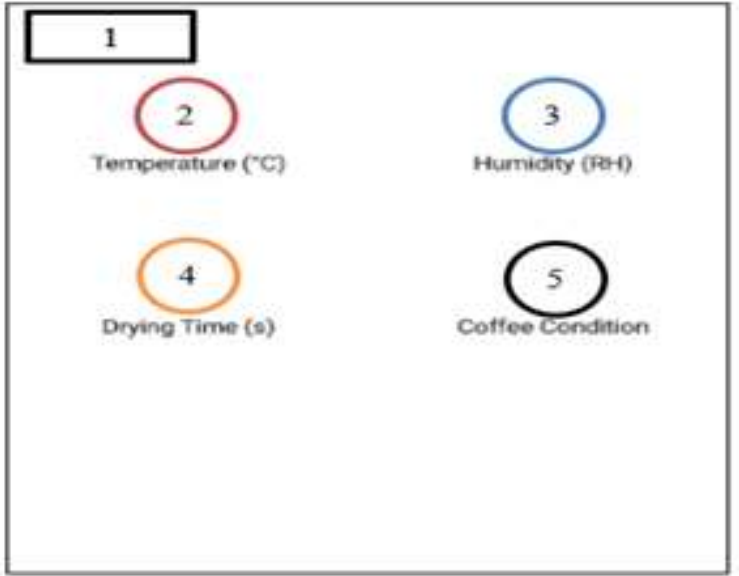

Gambar 4 Desain tampilan aplikasi

Implementasi dari perancangan elektrik sistem terdiri dari desain skematik elektrik atau hardware.

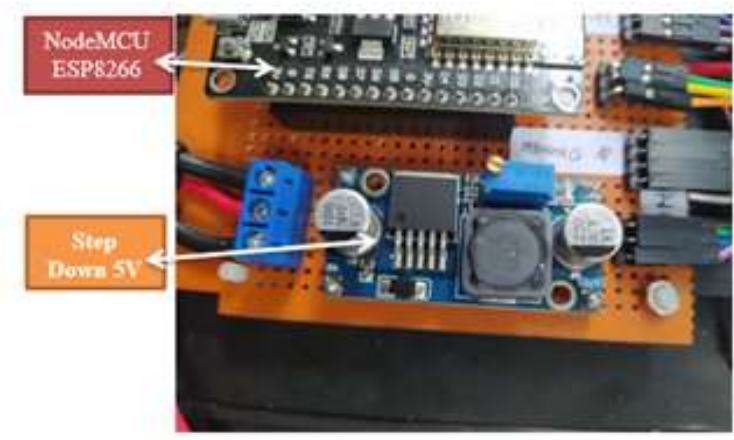

Gambar 5 Implementasi skematik rangkaian NodeMCU ESP8266

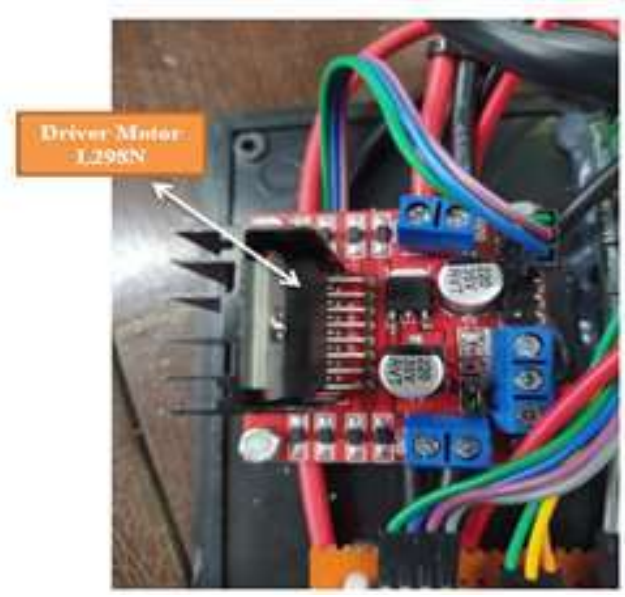

Gambar 6 Implementasi skematik rangkaian L298N

Implemntasi dari perancangan software ini akan menampilkan tampilan aplikasi monitoring melalui smartphone. Tampilan tersebut terdiri dari nilai suhu, kelembaban, waktu pengeringan dan kondisi biji kopi.
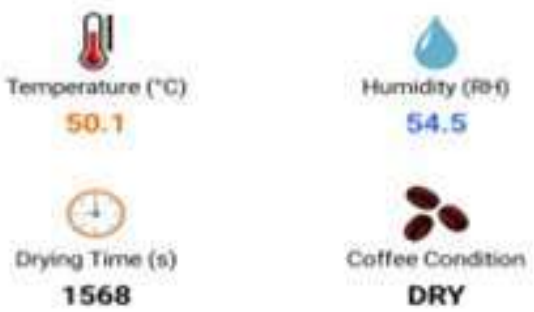

(n)

$+$

Gambar 8 Implementasi aplikasi kodular melalui smartphone

\section{HASIL DAN PEMBAHASAN}

\section{A. Pengujian Akurasi Sensor}

Pengujian akurasi sensor ini dilakukan dengan tujuan untuk mengetahui akurasi sensor DHT22 dengan membandingkannya menggunakan alat ukur Thermohygrometer sebagai referensi.

TABEL I

HASIL PENGUJIAN AKURASI SUHU

\begin{tabular}{|c|c|c|c|}
\hline No & $\begin{array}{c}\text { Suhu Thermo } \\
\text { Hygrometer } \\
\text { CC) }\end{array}$ & $\begin{array}{c}\text { Sensor Suhu } \\
\text { DHT22 ('C) }\end{array}$ & Deviasi Error \\
\hline 1. & 29,8 & 30 & 0,0101 \\
\hline 2. & 30,7 & 31 & 0,0163 \\
\hline 3. & 31,7 & 32 & 0,0094 \\
\hline 4. & 32,7 & 33 & 0,0153 \\
\hline 5. & 33,5 & 34 & 0,0178 \\
\hline 6. & 34,8 & 35 & 0,0057 \\
\hline 7. & 35,7 & 36 & 0,0112 \\
\hline 8. & 36,5 & 37 & 0.0220 \\
\hline 9. & 37,4 & 38 & 0,0242 \\
\hline 10. & 38,9 & 39 & 0,0209 \\
\hline 11 & 39,7 & 40 & 0,0204 \\
\hline 12 & 40,5 & 41 & 0,0123 \\
\hline 13 & 41,8 & 42 & 0,0047 \\
\hline 14 & 42,6 & 43 & 0,0093 \\
\hline 15 & 43,5 & 44 & 0,0114 \\
\hline
\end{tabular}


TABEL II

HASIL PENGUJIAN AKURASI KELEMBABAN

\begin{tabular}{|c|c|c|c|}
\hline No & $\begin{array}{c}\text { Kelembaban } \\
\text { Thermo } \\
\text { Hygrometer }\end{array}$ & $\begin{array}{c}\text { Sensor } \\
\text { Kelembaban } \\
\text { DHT22 }\end{array}$ & Deviasi Error \\
\hline 1. & 93,5 & 94 & 0,0054 \\
\hline 2. & 91 & 93 & 0,0219 \\
\hline 3. & 89 & 92 & 0,0337 \\
\hline 4. & 88 & 91 & 0,034 \\
\hline 5. & 86 & 89 & 0,0348 \\
\hline 6. & 85 & 87 & 0,0235 \\
\hline 7. & 82 & 84 & 0,0243 \\
\hline 8. & 79 & 81 & 0.0253 \\
\hline 9. & 74 & 78 & 0,054 \\
\hline 10. & 72 & 76 & 0,0555 \\
\hline 11 & 71 & 73 & 0,0281 \\
\hline 12 & 69 & 72 & 0,0434 \\
\hline 13 & 68 & 70 & 0,0294 \\
\hline 14 & 65 & 67 & 0,0307 \\
\hline 15 & 64 & 66 & 0,0312 \\
\hline 16 & 62 & 64 & 0,0322 \\
\hline 17 & 60 & 63 & 0,05 \\
\hline 18 & 58 & 56 & 0,037 \\
\hline 19 & 54 & 52 & 0,04 \\
\hline 20 & 50 & 51 & 0,0416 \\
\hline 21 & 51 & 49 & 0,0652 \\
\hline \multicolumn{3}{|c|}{ Rata-rata Persentase Error } & 0,0352 \\
\hline
\end{tabular}

\section{B. Pengujian Hasil Pengeringan Biji Kopi}

Pengujian hasil pengeringan biji kopi ini bertujuan untuk mengetahui nilai suhu, kelembaban mesin pengering saat proses pengeringan berlangsung dan lama pengeringan yang dibutuhkan. Langkah pertama sebelum dikeringkan biji kopi diberi perlakuan terlebih dahulu dengan cara melakukan fermentasi kering atau pemeraman selama 3 hari. Tetapi sebelum melakukan pemeraman biji kopi ditimbang sebanyak 250 gram pada masing - masing wadah. Kemudian dilakukan penimbangan ulang biji kopi setelah pemeraman selesai. Sebelum dilakukan pengeringan, berat biji kopi akan diukur menggunakan timbangan digital.

Gambar 9 merupakan merupakan hasil monitoring dari pengukuran sensor suhu DHT22 yang dilakukan pada jam 09:00 - 10:00 hari pertama dengan thermohygrometer sebagai pembanding. Berdasarkan hasil pengujian diatas terlihat bahwa nilai suhu DHT22 saat pengeringan biji kopi berkisar $30{ }^{\circ} \mathrm{C}-50{ }^{\circ} \mathrm{C}$. Sedangkan nilai suhu thermohygrometer berkisar $28,9^{\circ} \mathrm{C}-49,4{ }^{\circ} \mathrm{C}$. Suhu akan terus mengalami kenaikan dikarenakan heater sebagai pemanas dalam keadaan menyala, sehingga dapat menambah suhu didalam mesin pengering biji kopi.

Gambar 10 merupakan hasil monitoring dari pengukuran sensor kelembaban yang dilakukan pada jam 09:00 - 10:00 hari pertama dengan thermohygrometer sebagai pembanding. Berdasarkan hasil pengujian diatas terlihat bahwa nilai kelembaban DHT22 saat pengeringan biji kopi berkisar 95,2 \% - 51,9\%. Sedangkan nilai kelembaban thermohygrometer berkisar $92 \%$ - $51 \%$. Kelembaban akan semakin menurun ketika suhu semakin bertambah, dikarenakan nilai kelembaban berbanding terbalik dengan nilai suhu.

\section{Grafik Monitoring Sensor Suhu 09:00 - 10:00 (Hari ke 1)}

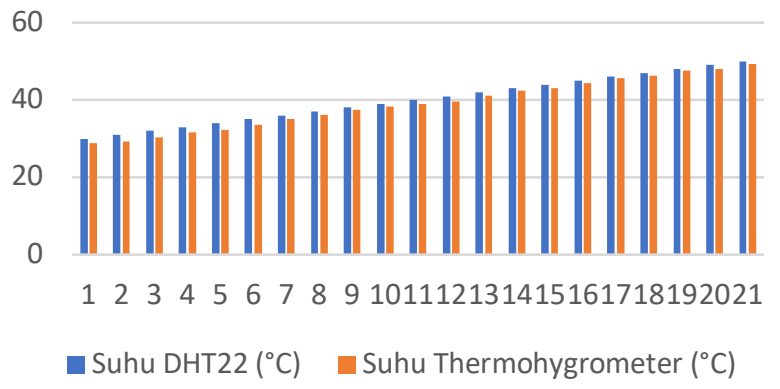

Gambar 9 Grafik monitoring sensor suhu

\section{Grafik Monitoring Sensor Kelembaban 09:00 - 10:00 (Hari ke 1)}

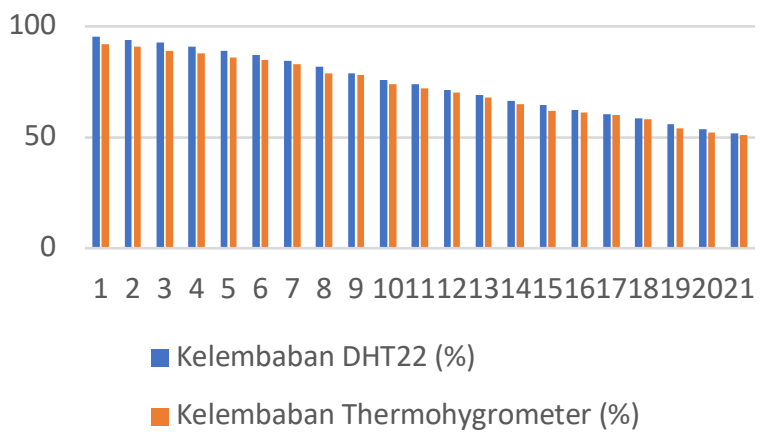

Gambar 10 Grafik monitoring sensor kelembaban

\section{Grafik Monitoring Sensor Suhu 19:00 - 20:00 (Hari ke 1)}

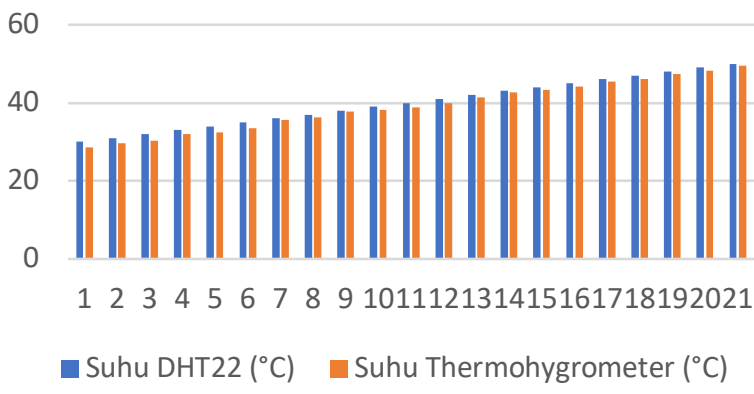


Gambar 13 merupakan hasil monitoring dari pengukuran sensor suhu DHT22 yang dilakukan pada jam 09:00 - 10:00 hari kedua dengan thermohygrometer sebagai pembanding. Berdasarkan hasil pengujian diatas terlihat bahwa nilai suhu DHT22 saat pengeringan biji kopi berkisar $30{ }^{\circ} \mathrm{C}-50^{\circ} \mathrm{C}$. Sedangkan nilai suhu thermohygrometer berkisar $28,5^{\circ} \mathrm{C}-$ 49, $4{ }^{\circ} \mathrm{C}$. Suhu akan terus mengalami kenaikan dikarenakan heater sebagai pemanas dalam keadaan menyala, sehingga dapat menambah suhu didalam mesin pengering biji kopi.

TABEL III

HASIL PENGUJIAN SIANG HARI keadaan menyala, sehingga dapat menambah suhu didalam mesin pengering biji kopi.

\section{Grafik Monitoring Sensor Kelembaban 19:00 - 20:00 (Hari ke 1)}

\section{0 \\ 50 0 \\ 123456789101112131415161718192021 \\ - Kelembaban DHT22 (\%) \\ - Kelembaban Thermohygrometer (\%)}

Gambar 12 Grafik monitoring sensor kelembaban

Gambar 12 merupakan hasil monitoring dari pengukuran sensor kelembaban yang dilakukan pada jam 19:00 - 20:00 hari pertama dengan thermohygrometer sebagai pembanding. Berdasarkan hasil pengujian diatas terlihat bahwa nilai kelembaban saat pengeringan biji kopi berkisar $70,7 \%$ - 47,6 \%. Sedangkan nilai kelembaban thermohygrometer berkisar $69 \%-46 \%$. Kelembaban akan semakin menurun ketika suhu semakin bertambah, dikarenakan nilai kelembaban berbanding terbalik dengan nilai suhu.

\section{Grafik Monitoring Sensor Suhu 09:00 - 10:00 (Hari ke 2)}

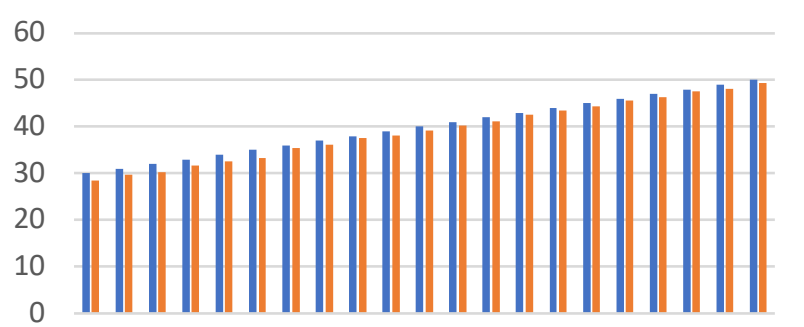

1223445677899101112131415161718192021

- Suhu DHT22 $\left({ }^{\circ} \mathrm{C}\right) \quad$ Suhu Thermohygrometer $\left({ }^{\circ} \mathrm{C}\right)$

Gambar 13 Grafik monitoring sensor suhu

\begin{tabular}{|c|c|c|c|c|c|c|}
\hline \multirow{3}{*}{$\begin{array}{c}\text { Berat } \\
\text { Biji } \\
\text { Kopi }\end{array}$} & \multicolumn{6}{|c|}{ PENGUJIAN SIANG HARI } \\
\hline & \multirow[b]{2}{*}{ No. } & \multicolumn{2}{|r|}{ DHT22 } & \multicolumn{2}{|c|}{ Thermohygrometer } & \multirow{2}{*}{$\begin{array}{c}\text { Durasi } \\
\text { Pengeringan }\end{array}$} \\
\hline & & $\begin{array}{l}\text { Suhu } \\
\text { ("Con }\end{array}$ & $\begin{array}{c}\text { Kelembaban } \\
(\%)\end{array}$ & $\begin{array}{l}\text { Suhu } \\
\text { ("C) }\end{array}$ & $\begin{array}{c}\text { Kelembaban } \\
\text { (\%) }\end{array}$ & \\
\hline \multirow{19}{*}{$\begin{array}{l}250 \\
\text { gram }\end{array}$} & 1 & 30 & 95.3 & 28.5 & 92 & \multirow{19}{*}{60 menit } \\
\hline & 2 & 31 & 93.6 & 29.7 & 91 & \\
\hline & 3 & 32 & 93 & 30.3 & 89 & \\
\hline & 4 & 33 & 91 & 31.6 & 88 & \\
\hline & 5 & 34 & 89.1 & 32.5 & 86 & \\
\hline & 6 & 35 & 87 & 33.3 & 85 & \\
\hline & 7 & 36 & 84.5 & 35.4 & 83 & \\
\hline & 8 & 37 & 82 & 36.1 & 79 & \\
\hline & 9 & 38 & 79 & 37.6 & 78 & \\
\hline & 10 & 39 & 76.1 & 38.2 & 74 & \\
\hline & 11 & 40 & 73.7 & 39.1 & 72 & \\
\hline & 12 & 41 & 71.6 & 40.3 & 70 & \\
\hline & 13 & 42 & 69.1 & 41.1 & 68 & \\
\hline & 14 & 43 & 66.4 & 42.5 & 65 & \\
\hline & 15 & 44 & 64.5 & 43.5 & 62 & \\
\hline & 16 & 45 & 62.4 & 44.3 & 61 & \\
\hline & 17 & 46 & 60.1 & 45.7 & 59 & \\
\hline & 18 & 47 & 58.4 & 46.3 & 58 & \\
\hline & 19 & 48 & 56.1 & 47.5 & 54 & \\
\hline
\end{tabular}

Grafik Monitoring Sensor Kelembaban 09:00 - 10:00 (Hari ke 2)

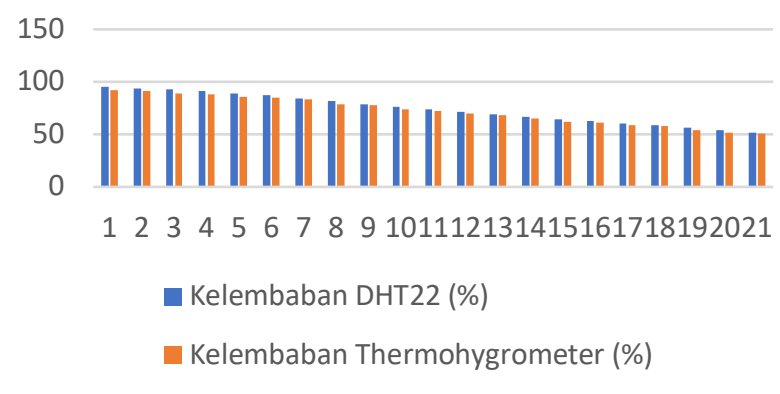

Gambar 14 Grafik monitoring sensor kelembaban

Gambar 14 merupakan hasil monitoring dari pengukuran sensor kelembaban yang dilakukan pada jam 09:00 - 10:00 hari kedua dengan thermohygrometer sebagai pembanding. Berdasarkan hasil pengujian diatas terlihat bahwa nilai 
kelembaban saat pengeringan biji kopi berkisar 95,3\% $52 \%$. Sedangkan nilai kelembaban thermohygrometer berkisar $92 \%$ - $51 \%$. Kelembaban akan semakin menurun ketika suhu semakin bertambah, dikarenakan nilai kelembaban berbanding terbalik dengan nilai suhu.

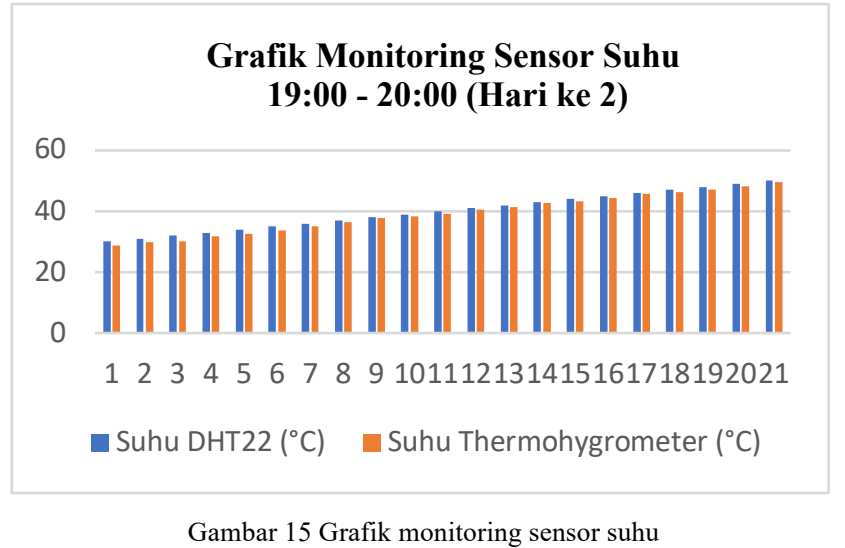

Gambar 15 merupakan hasil monitoring dari pengukuran sensor suhu DHT22 yang dilakukan pada jam 19:00 - 20:00 hari kedua dengan thermohygrometer sebagai pembanding. Berdasarkan hasil pengujian diatas terlihat bahwa nilai suhu DHT22 saat pengeringan biji kopi berkisar $30^{\circ} \mathrm{C}-50^{\circ} \mathrm{C}$. Sedangkan nilai suhu thermohygrometer berkisar $28,7^{\circ} \mathrm{C}-$ $49,5^{\circ} \mathrm{C}$. Suhu akan terus mengalami kenaikan dikarenakan heater sebagai pemanas dalam keadaan menyala, sehingga dapat menambah suhu didalam mesin pengering biji kopi.

\section{Grafik Monitoring Sensor Kelembaban 19:00 - 20:00 (Hari ke 2)}

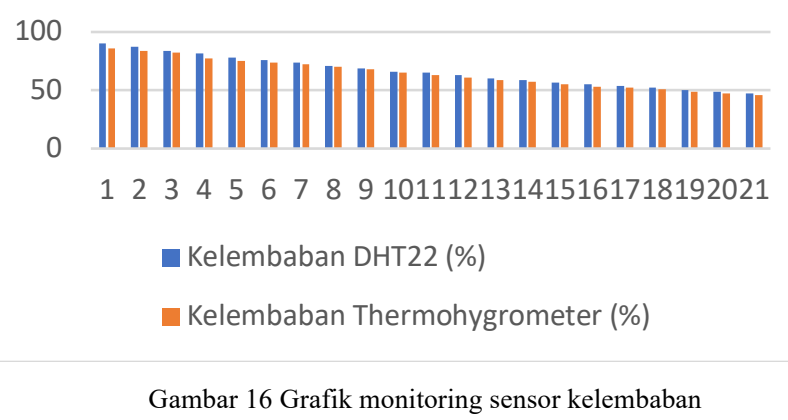

Gambar 16 merupakan hasil monitoring dari pengukuran sensor kelembaban yang dilakukan pada jam 19:00 - 20:00 hari kedua dengan thermohygrometer sebagai pembanding. Berdasarkan hasil pengujian diatas terlihat bahwa nilai kelembaban DHT22 saat pengeringan biji kopi berkisar $90,3 \%$ - 47,6 \%. Sedangkan nilai kelembaban thermohygrometer berkisar $86 \%$ - $46 \%$. Kelembaban akan semakin menurun ketika suhu semakin bertambah, dikarenakan nilai kelembaban berbanding terbalik dengan nilai suhu. Pengujian parameter delay dilakukan untuk mengetahui delay waktu saat pengiriman paket dari perangkat menuju user. Pengukuran delay menggunakan aplikasi Wireshark dengan mencari nilai urutan paket kemudian dihitung dengan mengurangi data yang diterima dan data yang dikirim. Berikut hasil pengujian delay yang dapat dilihat pada Tabel VII sebagai berikut :

TABel VII Hasil Pengujian Delay

\begin{tabular}{ccc}
\hline No. & Waktu (s) & Delay (s) \\
\hline 1 & 15 & 0,0252 \\
\hline 2 & 30 & 0,0241 \\
\hline 3 & 45 & 0,0264 \\
\hline 4 & 60 & 0,0256 \\
\hline & Rata-rata & 0,01 Second \\
\hline
\end{tabular}

Berdasarkan hasil pengujian delay pada Tabel B didapatkan hasil nilai delay terendah ada pada pengujian selama 30 detik yakni 0,0241 second, kemudian didapatkan hasil nilai delay tertinggi ada pada pengujian selama 45 detik yakni 0,0264 second. Dan untuk nilai rata-rata secara keseluruhan didapatkan hasil 0,01 second atau jika dikonversikan menjadi millisecond maka hasilnya 10 milisecond.

\section{KESIMPULAN}

Alat pengering biji kopi berbasis Internet Of Things dirancang dengan menggunakan elemen pemanas, sensor ultrasonic untuk mendeteksi biji kopi dan sensor DHT22 untuk mengukur nilai suhu dan kelembaban pada wadah pengering biji kopi.

Informasi tentang suhu dan kelembaban pada mesin pengering biji kopi saat proses pengeringan akan dikirim melalui NodeMCU ESP8266 menuju ke firebase google, kemudian manfaat dari Internet Of Things ialah dari aplikasi kodular dapat mengambil data berupa suhu, kelembaban relatif pada mesin pengering, waktu pengeringan dan kondisi biji kopi dari firebase sehingga dapat di monitoring melalui aplikasi kodular

Hasil pengukuran berat biji kopi sebelum pemeraman pada masing-masing wadah sebesar 250 gram sedangkan sesudah pemeraman sebesar 247 gram. Hal ini dikarenakan terjadi penurunan kadar air pada biji kopi.

Hasil pengujian pengeringan biji kopi pada siang hari pertama mendapatkan nilai suhu pada DHT22 berkisar $30^{\circ} \mathrm{C}$ - $50^{\circ} \mathrm{C}$ dengan kelembaban berkisar 95,2\% - 51,9\%. Nilai suhu thermohygrometer berkisar $28,9^{\circ} \mathrm{C}-49,4^{\circ} \mathrm{C}$ dengan kelembaban berkisar 92\% - 51\%, sedangkan untuk malam hari pertama nilai suhu DHT22 berkisar $30^{\circ} \mathrm{C}-50^{\circ} \mathrm{C}$ dengan kelembaban berkisar 90,2\% - 47,6\%. Kemudian nilai suhu thermohygrometer berkisar $28,5^{\circ} \mathrm{C}-49,5^{\circ} \mathrm{C}$ dengan kelembaban $88 \%$ - 46\%.

Hasil pengujian pengeringan biji kopi pada siang hari kedua mendapatkan nilai suhu pada DHT22 berkisar $30^{\circ} \mathrm{C}$ $50^{\circ} \mathrm{C}$ dengan kelembaban berkisar 95,3\% - 52\%. Nilai suhu 
thermohygrometer berkisar $28,5^{\circ} \mathrm{C}-49,4^{\circ} \mathrm{C}$ dengan kelembaban berkisar $92 \%-51 \%$, sedangkan untuk malam hari kedua nilai suhu DHT22 berkisar $30^{\circ} \mathrm{C}-50^{\circ} \mathrm{C}$ dengan kelembaban berkisar 90,3\% - 47,6\%. Kemudian nilai suhu thermohygrometer berkisar $28,7^{\circ} \mathrm{C}-49,5^{\circ} \mathrm{C}$ dengan kelembaban $86 \%$ - $46 \%$.

Proses pengiriman informasi dari perangkat menuju ke firebase google melalui koneksi internet yakni dibutuhkan waktu rata-rata 0,01 second atau 10 milisecond dengan ini delay termasuk dalam kategori sangat baik.

\section{REFERENSI}

[1] L. D. A. N. dan Y. M. Indraswari, "Rancang Bangun Penjemur Kopi Dengan Auto Reminder SMS Gateway." 2017.

[2] D. Pascapanen, D. A. N. Pembinaan, U. Direktorat, J. Perkebunan, and K. Pertanian, "Pedoman Teknis Penanganan Pascapanen Kopi," 2012.

[3] A. A. Dwirossi, "Rancang Bangun Sistem Monitoring Kadar Air Biji Kopi Pada Mesin Pengering Biji Kopi Berbasis Penjejak Matahari Aktif Dengan Mikrokontroler Atmega16," 2017.

[4] Y. Efendi, "Internet Of Things (Iot) Sistem Pengendalian Lampu Menggunakan Raspberry Pi Berbasis Mobile," J. Ilm. Ilmu Komput., vol. 4, no. 1, pp. 19-26, 2018, doi: 10.35329/jiik.v4i1.48.

[5] P. Organoleptik, P. Jenis, and K. Arabika, "Optimasi Penyangraian Terhadap Kadar Kafein Dan Profil Organoleptik Pada Jenis Kopi Arabika,” 2018.

[6] S. T. Hartini, "Aplikasi raspberry pi sebagai pengendali sistem pengeringan daun teh dengan perintah dan monitor dari smartphone," 2019.

[7] H. P. AS, "Fermentasi Teknologi OHMIC Parchment Coffee Beans (Kopi HS Basah) Terhadap Aroma," Tesis Keteknikan Pertan., 2018.

[8] H. Silitonga, "Pengontrol Suhu Ruangan Otomastis Menggunakan Nodemcu V3 Lolin dan Sensor DHT 11 Berbasis Internet," Repos. Institusi USU, pp. 1-44, 2019.

[9] R. H. Y. Perdana, Hudiono, M. Taufik, A. E. Rakhmania, R. M. Akbar, and Z. Arifin, "Hospital queue control system using Quick Response Code (QR Code) as verification of patient's arrival," Int. J. Adv. Comput. Sci. Appl., vol. 10, no. 8, 2019.

[10] N. Hidayati, L. Dewi, M. F. Rohmah, and S. Zahara, "Prototype Smart Home Dengan Modul NodeMCU ESP8266 Berbasis Internet of Things (IoT)," Tek. Inform. Univ. Islam Majapahit, pp. 1-9, 2018.

[11] R. H. Yoga Perdana, N. Hidayati, A. W. Yulianto, V. Al Hadid Firdaus, N. N. Sari and D. Suprianto, "Jig Detection Using Scanning Method Base On Internet Of Things For Smart Learning Factory," 2020 IEEE International IOT, Electronics and Mechatronics Conference (IEMTRONICS), 2020, pp. 1-5.

[12] Taufik, M., Hudiono, H., Rakhmania, A. E., Perdana, R. H. Y., \& Sari, A. S. (2021). An Internet of Things Based Intercity Bus Management System for Smart
City. International Journal of Computing and Digital Systems, 10.

[13] Satriya Dwi Ariffudin and D. Wulandari, "Perancangan Sistem Pemanas Pada Rancang Bangun Mesin Pengaduk Bahan Baku Sabun Mandi Cair Satriya Dwi Ariffudin," Jrm, vol. 01, no. 02, pp. 5257, 2014.

[14] B. Arsada, “Aplikasi Sensor Ultrasonik Untuk Deteksi Posisi Jarak Pada Ruang Menggunakan Arduino Uno," J. Tek. Elektro, vol. 6, no. 2, pp. 1-8, 2017.

[15] S. Sudarmaji, "Work System Analysis of Power Supply in Optimizing Electricity on Personal Computer (Pc)," Turbo J. Progr. Stud. Tek. Mesin, vol. 6, no. 2, pp. 168-177, 2017, doi: $10.24127 /$ trb.v6i2.554.

[16] Meriadi,S.Meliala,and Muhammad, "Menggunakan Pemanas Listrik,” J. Energi Elektr., vol. 7, pp. 47-53, 2018. 